\title{
Methodology for treatment and evaluation of locomotive capability of patients after traumatic spinal cord injury
}

\author{
Magdalena Sobiech, Małgorzata Drelich, Karolina Turżańska, Jaromir Jarecki, Mirosław Jabłoński
}

Chair and Clinic of Rehabilitation and Orthopaedics, Medical University of Lublin, Poland

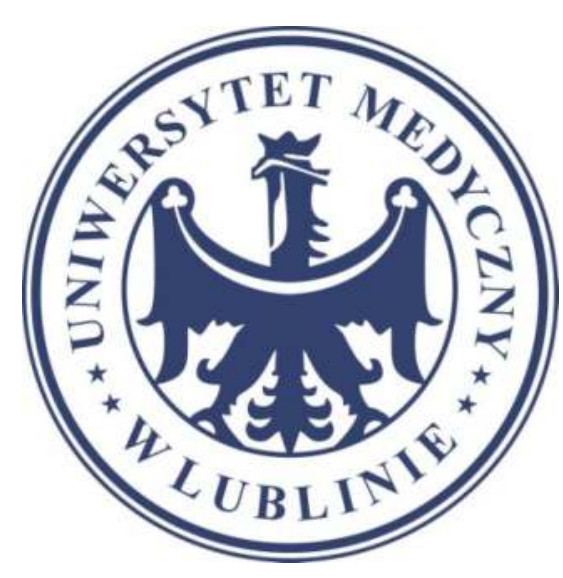

Key words:

Paralysis, paresis, rehabilitation, verticalization, orthopaedic appliances

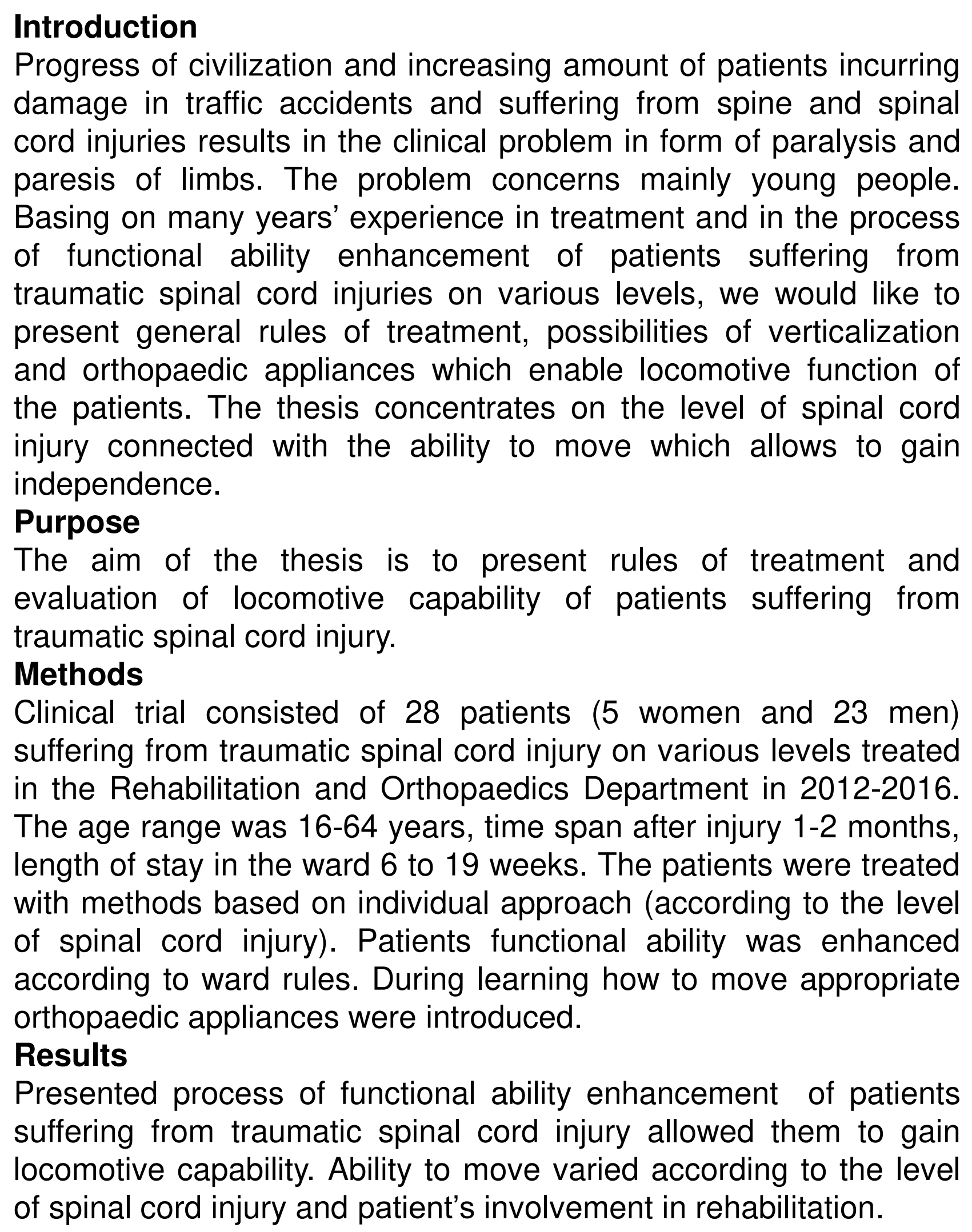

Progress of civilization and increasing amount of patients incurring damage in traffic accidents and suffering from spine and spinal cord injuries results in the clinical problem in form of paralysis and paresis of limbs. The problem concerns mainly young people. Basing on many years' experience in treatment and in the process of functional ability enhancement of patients suffering from traumatic spinal cord injuries on various levels, we would like to present general rules of treatment, possibilities of verticalization and orthopaedic appliances which enable locomotive function of the patients. The thesis concentrates on the level of spinal cord injury connected with the ability to move which allows to gain independence.

Purpose

The aim of the thesis is to present rules of treatment and evaluation of locomotive capability of patients suffering from traumatic spinal cord injury.

\section{Methods}

Clinical trial consisted of 28 patients (5 women and 23 men) suffering from traumatic spinal cord injury on various levels treated in the Rehabilitation and Orthopaedics Department in 2012-2016. The age range was 16-64 years, time span after injury 1-2 months, length of stay in the ward 6 to 19 weeks. The patients were treated with methods based on individual approach (according to the level of spinal cord injury). Patients functional ability was enhanced according to ward rules. During learning how to move appropriate orthopaedic appliances were introduced.

Results

Presented process of functional ability enhancement of patients suffering from traumatic spinal cord injury allowed them to gain locomotive capability. Ability to move varied according to the level of spinal cord injury and patient's involvement in rehabilitation.

\section{References}

1. Kędziora P., Lizis P., Znojek-Tymbowska J., Hagner-Derengowska M., Szczygielska-Babiuch A. Wpływ aktywnej rehabilitacji na sprawność samoobsługi i lokomocji osób po urazie rdzenia kręgowego. Journal of Health Sciences 2012; 2940, $271-282$.

2. Sosnowski S., Kurczewski M., Kaładyńska M., Zakrzewska K. Proces aktywnej rehabilitacji chorych po urazach rdzenia kręgowego. Ortopedia , Traumatologia, Rehabilitacja 2000; 1, 53-56.

3. Furmaniak L., Cywińska-Wasilewska G. Metodyka usprawniania osób po urazie rdzenia kręgowego podczas obozów Aktywnej Rehabilitacji. Fizjoterapia 2008, 16, 1. 85-91.

4. Cywińska - Wasilewska G. Ocena sprawności funkcjonalnej chorych z urazowym uszkodzeniem rdzenia kręgowego. Ortopedia, Traumatologia i Rehabilitacja. 2002, 6, 747-751.

5. Drużbicki M. Kwolek A., Depa A. Pionizacja w procesie rehabilitacji chorych z objawami ogniskowego uszkodzenia ośrodkowego układu nerwowego- nowe możliwości aparaturowe. Przegląd Medyczny Uniwersytetu Rzeszowskiego, Rzeszów 2008, 1,14-20

6. Marcinek J., Szewczenko A. Sprzęt szpitalny i rehabilitacyjny, Wydawnictwo Politechniki Śląskiej 2003.

7. Przeździak B. Zaopatrzenie rehabilitacyjne, Via Medica, Gdańsk 2003.

8. Józefowski P., Bolach B., Tetyana P. Analiza sprawności funkcjonalnej osób z tetraplegią podczas obozu I stopnia Aktywnej Rehabilitacji.

Pedagogika i psychologia 2011,

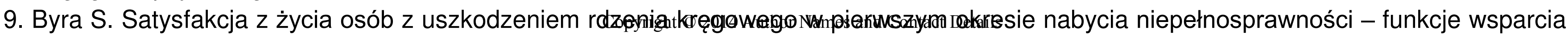
otrzymywanego i oczekiwanego. Medycyna Ogólna i Nauki o Zdrowiu , 2011, tom 17,nr 2, 64-70. 